\title{
THE IMPACT OF HUNTING FOR BILTONG PURPOSES ON THE SA ECONOMY
}

\author{
Melville Saayman: Institute for Tourism and Leisure studies - North West University \\ Peet van der Merwe: Institute for Tourism and Leisure studies - North West University \\ Riaan Rossouw: School of Economics - North West University
}

\begin{abstract}
Purpose: The purpose of this article is to estimate the economic impact of biltong hunting in South Africa.
Problem investigated: Higginbottom (2004), indicate there are no reliable global estimates of the economic impact of wildlife tourism, but one thing is certain, it generates considerable sums of money. This same accounts for South Africa's game industry, especially biltong hunting, where there is little to no information regarding the economic impact. Therefore the question to be investigated was what is the economic impact of biltong hunting in the South African economy.
\end{abstract}

Research methodology: A non-probability method was used and a convenience sample was drawn from all the members $(\mathrm{N}=$ 17066) of the South African Hunters and Game Conservation Association (SAHGCA). A pilot study of 87 questionnaires was conducted in August and September 2004 in the North West Province at the Hartbees branch of SAHGCA. For the national survey, the questionnaires were mailed together with the members' monthly magazine (named SA Hunters/Jagters) during July 2005. A total of 1024 (n) questionnaires were received back. Data was captured in Microsoft ${ }^{\mathrm{TM}}$ Excel $^{\mathrm{TM}}$ and a Computable General Equilibrium (CGE) modelling approach was thereafter used to determine the economic impact of biltong hunting in the South African economy.

Findings/implications: The contribution to real GDP is estimated to be in excess of R6 billion, with thousands of jobs being created by the increase in activities/services. In addition, the related improvements to the infrastructure of the country, especially the transport sector, will benefit productivity in the longer term and so lead to further increases in GDP.

Originality: A significant contribution that this article has made is that this is the first time that the economic impact of biltong hunting in South Africa has been determined. It is also the first time that CGE modelling has been completed with regard to research in this sector in South Africa.

Conclusion: This supports the opinion that biltong hunting is a viable and important sector of the tourism industry. The results clearly show that more should be done to expand hunting in South Africa as hunting affects, not only the economy, but also the price (and therefore the value) of game.

Key words and phrases: biltong hunting, CGE modelling, economic impact, hunting, tourism, South Africa, wildlife tourism.

\section{INTRODUCTION}

A good indicator of the growth in tourism is foreign tourist arrivals to South Africa, which increased from 5.87 million in 2000 to 7.3 million in 2005. Over nine years, from 1995 to 2004, the percentage increase was 48.7\% (South African Annual Tourism Report, 2004). In South Africa, the government's Accelerated and Shared Growth Initiative for South Africa (AsgiSA) identified tourism as an important sector and globally it is recognised as both the largest and the fastest growing industry. Statistics support this contention: in 2005, worldwide travel and tourism was expected to generate economic activities worth US\$6 201.49 billion, 10.6\% of the total GDP, and 221568000 jobs or $8.3 \%$ of total employment (World Travel and Tourism Council, 2005). Nature-based tourism is one sector of the tourism industry that is attracting increasing interest from 
governments, the tourism industry and researchers alike. This type of tourism includes activities such as whale watching, safaris, bird watching, fishing and hunting, to mention merely a few of many. According to Higginbottom (2004), nature-based tourism is widely considered as a growth sector that can contribute substantially to the economy of its host country.

From the above, it can be extrapolated that nature-based tourism is very reliant on the conservation and preservation of natural resources. Like South Africa, countries such as Kenya, Botswana, Tanzania, Australia and Canada also make use of nature-based tourism to attract ever-growing markets to their shores. Currently, 3.7 million hectares (ha) of land are conserved through South Africa National Parks (SANParks), which holds $3 \%$ of the total agricultural land available in South Africa (Phillips, 2005). Privately owned land, such as game farms under conservation, constitutes $17.9 \%$ of the total agricultural land in South Africa, or 14.7 million ha (6330 exempted game farms) (Van Hoven, 2005). One of the main sources of income for game farms is hunting (Van der Merwe et al., 2004).

\section{Tourism and Hunting in Perspective}

Game is hunted for biltong (dried meat) or for trophies and, in some cases, for both purposes. Various forms of hunting take place, for example bird hunting, bow hunting, biltong hunting, trophy hunting, 'green hunting' or 'darting safaris' (Van der Merwe \& Saayman, 2004). Saayman et al. (2000) determined that the following economic benefits originated from the development of the hunting industry:

Hunting is exportable. Meat, trophies and skins are some of the products that are exported.

Hunting creates income. In the case of government, it broadens the tax base and is a major source of income for the game farm owner.

Hunting creates job opportunities. Hunting is a labour-intensive market and, because of its diversity, creates a wide range of jobs. The jobs can be in the primary hunting sector (people who work directly in the hunting industry, such as on game farms, in taxidermies, hunting outfitters and lodges) or secondary providers (people who work indirectly in the tourism industry, for example, providing infrastructure and suprastructure, or agriculture).

Hunting generates foreign exchange. Foreign hunters spend in excess of R50 000 per hunter in South Africa (PHASA, 2006).

Hunting creates entrepreneurial opportunities. These include accommodation, food, transport, entertainment, clothes, souvenirs, travel agencies, and many more.

Further, Thornton and Feinstein (1999) indicated other advantages from the spending of biltong hunters: development of supra-structures, as additional game farms are developed to cater for the demand for hunting and for the conservation and hunting of specific species. This also leads to the creation of expensive lodges to cater for different markets.

Expenditure by tourists (hunters in this case) directly affects the tourism industry and also has an indirect impact on other sectors of the economy such as agriculture, manufacturing, food processing, and communication. It also contributes to services such as banking, foreign exchange transactions, postal services, transport and insurance (Futter \& Wood, 1997). Table 1 specifies the direct and indirect impacts of hunting. 
Table 1: Direct and indirect impacts

\begin{tabular}{|c|c|}
\hline Direct impact & Indirect impacts \\
\hline $\begin{array}{ll} & \text { Value of game hunted } \\
\text { - } & \text { Accommodation } \\
\text { - } & \text { Transport costs } \\
\text { - } & \text { Firearm dealers (ammunition, rifles) } \\
\text { - } & \text { Butcheries (meat processing) } \\
\text { - } & \text { Taxidermies } \\
\text { - } & \text { Curios shops } \\
\text { - } & \text { Petrol stations } \\
\end{array}$ & $\begin{array}{ll}\text { - } & \text { Food and refreshments } \\
\text { - } & \text { Payment of hunters' employees } \\
\text { - } & \text { New vehicle } \\
\text { - } & \text { Hunting equipment (binoculars) } \\
\text { - } & \text { Clothing and shoes } \\
\text { - } \quad \text { Staff spending at local businesses } \\
\text { - } \quad \text { Salaries of staff } \\
\text { - } \quad \text { Servign exchange } \\
\end{array}$ \\
\hline
\end{tabular}

The fact that tourism is not yet reported as an industry in the national accounts makes it very difficult to determine the exact economic impact of tourism, as many other sectors contain tourism-related activities in their estimates (Bull, 1993; Saayman, 2001). The economic contribution made by tourism is therefore greater than at first sight because many of the other economic sectors contain tourism-related activities in their estimates. The underestimation of the complex nature of the tourism industry means that the contribution of tourism is not always seen as an important area of potential economic growth and development (Vellas \& Becherel, 1995). According to Van der Merwe and Saayman (2005b), this is particularly the case when examining the hunting industry. Currently, the South African government, at all levels, is doing very little to promote hunting but is, on the contrary, implementing barriers. One example is the new firearms legislation that makes ownership and provision of hunting weapons more difficult (Venter, 2006).

To estimate economic impacts, normally the additional 'new money' generated for the local economy due to tourism is considered (Gelan, 2003). Within the tourism sector, tourists visiting a province or region usually create this 'new money'. From a regional perspective, both foreign and domestic tourists (hunters) visiting the region represent 'new money', while day excursions to the region are excluded.

Economic impact is defined as the net economic change in a host community that results from the spending of tourist (hunters) in a given area (Ritchie \& Goeldner, 1994). Therefore, it can be said that the purpose of an economic impact analysis is to measure the economic benefits that a community receives (Van Heerden, 2003; Fayos-Sola, 1997; Archer, 1989). These benefits will help to enhance the way of life, the economy and the environment of the host population. However, the magnitude of the economic impact of tourism depends on the total number of tourists (hunters) who visit an area/country, the duration of their stay, the average spending of tourists (hunters) in that area/country, and the circulation of tourism expenditure through the country (Saayman, 2000).

Getz (1993) rightfully indicates that the spend of tourists (hunters) plays a significant role in enhancing the economy of local communities, and can have additional spin-offs, such as increased investment in, for example, the building of new hunting lodges, the development of new game farms, taxidermies, and craft manufacturing. Economic impact analysis is an important analytical tool in order for stakeholders to determine the economic benefits of their industry. This is equally true for the tourism (hunting) industry. There are essentially two main benefits from conducting economic impact studies, namely approvals and advocacy.

Approvals means economic impact studies provide government structures with information on projects that seek funding, subsidies, tax incentives or other forms of regulatory assistance. They provide project proponents with additional information and analysis when negotiating with various levels of government concerning development approvals or various forms of assistance. 
Advocacy and support means economic impact studies assist in giving a value to the economic benefits of hunting in terms of jobs and other economic activities. These valuations can then be used to persuade the various stakeholders, such as game farms, local communities, employees and clients/customers, of those benefits in order to advocate the industry and to gain the support of stakeholders (Koch, 2005; Bauer \& Herr, 2004).

Various economic impact studies have been conducted, for example, Kang and Perdue (1994) and Gelan (2003) on sport tourism. Saayman and Saayman (1997), Kottke (1988), Zhou et al. (1997), Fretchling and Horvath (1999), Randall and Warf (1996) have all conducted studies. Walpole and Goodwin (2000) focussed on regional and country economic impacts. Saayman and Saayman (2004), Fayos-Sola (1997) and Van Heerden (2003) examined the economic impact of events. Tisdell and Wilson (2004), Nijkamp (2004) and Getzner et al. (2005) have undertaken economic impact studies regarding wildlife tourism. However, no economic impact study has been completed with regard to hunting, as far as could be established from the literature review.

According to Higginbottom (2004), there are no reliable global estimates of the economic impact of wildlife tourism, but it certainly generates considerable sums of money. The same can be said for South Africa's game industry, especially biltong hunting, where there is little to no information regarding the economic impact. Trophy hunting, according to PHASA (2006), generated approximately R650 million in 2005 and a study conducted by Van der Merwe and Saayman (2005c) in the North West Province indicated biltong hunters contributed R191 million.

Research regarding hunting and its contribution to local, regional and national economies can assist practitioners in developing hunting policies, which can cover a variety of aspects. These aspects could include a number of themes such as how hunting can contribute to the economic growth of a province, to job creation, to game farm management as well as for marketing purposes (Saayman \& Saayman 2006).

The purpose of this article is to estimate the economic impact of biltong hunting in South Africa.

\section{METHOD OF RESEARCH}

The research was conducted using a questionnaire consisting mostly of closed-response questions, with a few open-ended questions. The questionnaire was developed in co-operation with the South African Hunters and Game Conservation Association (SAHGCA) and the Institute for Tourism, Wildlife Economics and Leisure Studies at the North-West University, Potchefstroom Campus. A pilot study of 87 questionnaires was conducted in August and September 2004 in the North West Province.

A non-probability method was used, where all SAHGCA members $(\mathrm{N}=17066)$ formed part of the sample. SAHGCA is the largest hunting association recognised by the South African government. Cooper and Emory (1995) state that for a population of 100000 the recommended sample size is 384 . However they also indicated that as a rule of thumb the law of diminishing returns will apply when the sample size is greater than 300.

For the national survey, questionnaires were mailed in July 2005 to the full complement of members $(\mathrm{N}=17066)$ included in their monthly magazine SA Hunters/Jagters. Reminders were sent during August 2005. The cut-off date for receiving questionnaires was set for the end of August 2005. A total of 1024 (n) questionnaires were received, which represented a $6 \%$ return rate. Data was captured in MS Excel ${ }^{\mathrm{TM}}$ and then a Computable General Equilibrium (CGE) modelling approach was used to determine the economic impact of biltong hunting on the South African economy. 
A CGE model is a model of the economy that recognises that the economy is a complete system of interdependent components (industries, households, investors, government, importers, and exporters). Economic impacts affecting any one component can have repercussions throughout the economic system. A CGE model is constructed using a Social Accounting Matrix (SAM) combined with a conceptual framework that contains the behavioural and technical relationships among variables within and among sets of accounts.

These models thus aim to convert the abstract representation of an economy into realistic, resolvable models of actual economies (Cameron, 2003). What makes CGE models even more realistic is that they incorporate trade elasticities. CGE modelling can, therefore, be used for more detailed and realistic evaluations of the economy-wide effects of policy changes or other economic impacts than either Input-Output or Social Accounting Matrices (Zhang \& Lee, 2007; Tyler, 2008; Resosudarmo, 2008).

The UPGEM model used in these simulations is a 32-sector CGE model of the South African economy derived from the ORANI-G model of the Australian economy. The version used distinguishes 32 sectors, 6 household types and 4 ethnic groups.

The UPGEM, similar to other CGE models, is designed for comparative-static simulations (Horridge, 2000). The data was compiled using a Social Accounting Matrix (SAM), which perfectly describes the economy at any given time. Economic participants are assumed to be price takers working in a competitive market. It is also assumed that supply and demand equations for the private-sector agents are derived from the solutions to the optimisation problems e.g. cost minimisation and utility maximisation (Horridge, 2000). Furthermore, the UPGEM model consists of a theoretical structure which is typical of a static Applied General Equilibrium (AGE) model and is also based on a number of sectors, industries and commodities. The variables in the model are each explained by an equation and these variables are either endogenous or exogenous. Endogenous variables are explained by the model, while exogenous variables are user-defined or are assumed to be fixed. Only exogenous variables can be shocked or impacted.

CGE models are used mainly for comparative static analyses. This form of analysis involves comparing equilibrium positions as opposed to examining the path which the market follows when moving from the old to the new equilibrium. Therefore, the changes in a system from one position of equilibrium to another are investigated, without regard to the transitional process involved in the adjustment (Zamagni, 1987). Results of comparativestatic CGEs all refer implicitly to the economy at some future time period.

\section{Model Closure, Data and Shocks}

In order to simulate correctly the impact of the expenditure of hunters on the South African economy, it is critical to use an appropriate model closure (that is, the selection of variables that are chosen to be exogenous). This study focuses primarily on the expenditure of the estimated 200000 hunters in South Africa and the impact of this expenditure on the local economy. The two most important outcomes to take note of would be the impact on employment and on GDP. The standard short-run and long-run closures were thus used to simulate the results.

As mentioned above, the nature of the comparative-static CGE model does not require time series data, but is compiled instead from a SAM. The database of the UPGEM model is based on the values of the 1998 SAM of the South African economy published by Statistics South Africa, which implicitly describes the structure of the local economy at that particular time.

The shocks applied to the economy are based on the average expenditure of hunters in the various sectors of South Africa's economy. This expenditure will obviously greatly benefit the service sectors, such as hotels and other accommodation, transport, and health services, for example, and is included in the simulations. 
By comparing the expenditure of the 200000 hunters in the relevant sectors to the total expenditure in South Africa, the percentage shocks to the industries were calculated and the impact thereof simulated using the UPGEM model. It was decided to shock the real household consumption with an increase of $2.16 \%$ and to shock the expenditure of households in selected sectors. This was done in order to simulate the effect of the increased expenditure by households in the various sectors in general. The main findings of the simulation are reported in the next section.

\section{RESULTS}

The results will be discussed in two sections: firstly, the profile of hunters will be examined and, secondly, the economic impact of the biltong hunters.

Table 2 reveals the profile of biltong hunters in South Africa. Almost all (98\%) of the hunters are males between the ages 40-64 years of age, over two-thirds (68\%) prefer to hunt in a group (4 persons) and hunt at least three times per year. Nearly half of them, (48\%) earn more than R250 000 per annum and $22 \%$ are self employed

Table 2: National biltong hunter profile

\begin{tabular}{|l|l|}
\hline Category & Results \\
\hline Gender & $98 \%$ male \\
\hline Language & $87 \%$ Afrikaans \\
\hline Age & $63 \%$ between $40-64$ years of age \\
\hline Marital status & $89 \%$ married \\
\hline Level education & $69 \%$ had some form of post-matric qualifications \\
\hline Preferred magazine & SA Hunter (38\%) and Magnum (28\%) \\
\hline Occupation & $22 \%$ Self employed, 18\% Administrative, 18\% Manager \\
\hline Income & $48 \%$ earn more than R250 000 per annum \\
\hline Prefer to hunt & $68 \%$ hunt in a group (average size 4 persons) \\
\hline Mode of transport & $39 \%$ use a 4x4 and 44\% use a pick-up (bakkie) \\
\hline Times gone hunting & 3 times per year \\
\hline Preferred country & South Africa \\
\hline Preferred provinces & Limpopo (37\%), Northern Cape (15\%) and North-West (14\%) \\
\hline Average length of stay & 4 days \\
\hline Average number of species hunted & 5 species \\
\hline
\end{tabular}

Table 3 shows the expenditure per hunter excluding expenditure on game. While on a hunting safari, hunters spent R4130.00 on general expenses and R11 622.37 on game. This results in a total of R15 752.37 that biltong hunters spend per year on hunting.

\section{Simulation Results}

When interpreting the findings of the different scenarios, it is essential to keep in mind the type of closure used. The simulation results of the shocks applied to the economy depend to a large extent on the model closure. In the standard short-run closure, variables constraining real GDP from the expenditure side such as the total amount of private consumption, investment, and government consumption are exogenous and the percentage change to these variables will be zero. The level of employment and the trade balance are endogenous, and their effects on real GDP are therefore solved within the model. (An in-depth discussion on the closure of a model can be found in Horridge (2000)). Keeping in mind the restrictions of the specific 
closure used and the nature of the different simulation scenarios, the following macro-economic results were obtained for the given shocks applied to the economy.

Table 3: Average Expenses Excluding Game

\begin{tabular}{|l|c|}
\hline Category & Total Expenditure per season in Rand (excluding game) \\
\hline Accommodation & 869.00 \\
\hline Fuel & 734.00 \\
\hline Food & 452.00 \\
\hline Meat processing & 417.00 \\
\hline Ammunition & 279.00 \\
\hline Hunting gear & 278.00 \\
\hline Daily fees & 260.00 \\
\hline Alcohol and beverages & 245.00 \\
\hline Butcher facilities & 229.00 \\
\hline Clothing & 139.00 \\
\hline Other & 102.00 \\
\hline Medicine & 54.00 \\
\hline Toiletries & 51.00 \\
\hline Tobacco & 21.00 \\
\hline Total Expenditure & $\mathbf{R 4 1 3 0 . 0 0}$ \\
\hline
\end{tabular}

Table 4: Selected macro-economic variables

\begin{tabular}{|l|l|}
\hline Macros & Simulation 1 \\
\hline$\% \Delta$ in real GDP (x0gdpexp) & 0.60 \\
\hline$\% \Delta$ in employment (employ_iop) & 1.10 \\
\hline$\% \Delta$ in consumer prices (p3tot) & 1.28 \\
\hline$\% \Delta$ in price of labour (p1lab_iop) & 1.28 \\
\hline$\% \Delta$ in total exports (x4tot) & -1.94 \\
\hline$\% \Delta$ in competitiveness (p0realdev) & -1.27 \\
\hline$\% \Delta$ in balance of trade (contBOT) & -0.98 \\
\hline
\end{tabular}

The majority of macro-economic variables selected clearly showed an improvement after the shocks were applied. In simulation 1, real GDP growth (x0gdpexp) increased by $0.60 \%$, equating to a contribution of more than $\mathrm{R} 6$ billion to the economy. The simulation results also indicated that employment levels would improve by $1.10 \%$ due to the shock, equating to the creation of more than 140,000 jobs. The increase in activities/services would be expected to increase employment, particularly in the semi- and un-skilled labour segments. Inflation would tend to increase due to the increase in real wages caused by the various shocks. The price level of goods and services (p3tot), and nominal wages (p1lab_iop) would both increase by $1.28 \%$. The increase in the general level of prices could be due to the fact that the increase in real wages would then force nominal wages to increase by the same amount. The decrease in total exports is directly attributable to the decrease in international competitiveness (p0realdev) of locally produced goods and services. Higher costs of domestic goods would, in theory, lead to a decrease in demand from foreign countries and therefore a decrease in total domestic exports.

When examining the changes to real GDP from the expenditure side through the contGDPexp variable, the contribution of each sector to the GDP can be isolated. The results are shown in the table below. 
Table 5: Contribution to changes in GDP from the expenditure side

\begin{tabular}{|l|l|}
\hline contGDPexp & Simulation $\mathbf{1}$ \\
\hline Consumption & 1.57 \\
\hline Investment & 0 \\
\hline Government & 0 \\
\hline Stocks & 0 \\
\hline Exports & -0.65 \\
\hline Imports & -0.33 \\
\hline
\end{tabular}

Consumption would increase due to the increase in expenditure in the various sectors (due to the shock applied) and the higher employment levels. Investment, government and stocks are exogenous in the closure and changes in these variables are therefore zero. Due to the relatively higher domestic prices, as indicated by the p3tot variable in Table 4 , the foreign demand for local exports would decrease by $0.65 \%$ overall. The demand for imports would also decrease slightly due to the higher consumption of domestic goods. The net effect of changes in imports and exports of $-0.98 \%$ corresponds to the percentage change in the balance of trade (contBOT) variable shown in Table 4 . The cumulative change of $0.60 \%$ from the various sectors indicated in Table 5 corresponds to the percentage change in real GDP (x0gdpexp) of $0.60 \%$ as previously discussed.

From an industry specific point of view, it is interesting to note which industries are affected most favourably. The results for key selected industries are shown in Table 6 below.

Table 6: Percentage change in activity level of selected industries

\begin{tabular}{|l|l|}
\hline $\mathbf{x}$ 1tot & Simulation $\mathbf{1}$ \\
\hline Food processing & 1.71 \\
\hline Construction \& electricity & 0.90 \\
\hline Accommodation & 0.85 \\
\hline Business activities & 1.40 \\
\hline Clothing & 0.13 \\
\hline Footwear & 1.92 \\
\hline Beverages & 1.28 \\
\hline Tobacco & 1.29 \\
\hline Transport & 0.82 \\
\hline Other activities/services & 1.50 \\
\hline
\end{tabular}

Industries such as food processing, business activities, footwear, beverages, tobacco and other services/activities are amongst the greatest winners. In general, the results are as expected with most related industries showing positive gains, even though very moderate ones.

\section{CONCLUSION}

The goal of this paper was to estimate the economic impact of biltong hunting on the South African economy.

This simulation examined the impact of expenditure by hunters on the South African economy using a CGE modelling approach. The results from the UPGEM model show that this expenditure has a positive impact on the South African economy. The contribution to real GDP is estimated to be in excess of R6 billion, with thousands of jobs being created by the increase in activities/services. In addition, the related improvements to the infrastructure of the country, especially the transport sector, will benefit productivity in the longer term and so lead to further increases in GDP. Given the likelihood that the number of hunters in South Africa will 
increase over the next decade, (this increase in numbers has not been included in the current simulation), it can be expected with relative certainty that the country as a whole will benefit significantly in terms of higher economic growth and higher levels of employment.

This article has made a significant contribution, as it is the first time that the economic impact of biltong hunting in South Africa has been determined. It is also the first time that CGE modelling has been completed with regard to research in this sector in South Africa. This research confirms that hunting should be regarded as big business and has significant impacts on various other sectors in the economy. From a policy point of view, it is important for government both to realise the significance of the economic impact and to note that hunting can be used to increase wealth in poorer provinces (the provinces where most hunting takes place). Hence, it is important to increase the number of hunters, as well as to promote hunting establishments more effectively. Saayman and Van der Merwe (2005a) already alluded to the fact that hunting is important for the sustainability of game farms in South Africa, since a greater demand for game will guard against volatility in game prices. Currently, the supply of game is increasing rapidly, which could have far-reaching consequences for the price (value) of game.

This research also proved a need for more research to be conducted into the hunting and game farm sector. For example, the economic impact of trophy hunting to the South African economy should be determined. Similarly, the socio-economic impact of hunting and game farms also needs to be researched. 


\section{REFERENCES}

ARCHER, B. 1989. Tourism and island economies: impact analysis. (In Cooper, C.P., ed. Progress in Tourism, Recreation and Hospitality Management. London: Belhaven Press. p. 125-134.).

BAUER, J. \& HERR, A. 2004. Hunting and fishing tourism. (In Higginbottom, K., ed. Wildlife Tourism: Impacts and Planning. Altona vic: Common Ground Publishing. p. 57-75.)

BULL, A. 1993. The Economics of Travel and Tourism. Melbourne: Pitman Publishing..

CAMERON, M.J. 2003. The relationship between Input-Output (IO) analysis, Social Accounting Matrices (SAM) and Computable General Equilibrium (CGE) models in a nutshell. Internal working paper. Global Insight Southern Africa. October 2003.

COOPER, D.R. \& EMORY, W. 1995. Business research methods. Chicago: Irwin.

FRETCHLING, D.C. \& HORVATH, E. 1999. Estimating the multiplier effect of tourism expenditure on a local economy through a regional input-output model. Journal of travel research, 37(4):324-33.

FAYOS-SOLA, E. 1997. The Impact of Mega-events. Annals of tourism research, 25(1):241-244.

FUTTER, M. \& WOOD, L. 1997. Tourism and development: no short cuts. Indicator South Africa, 14(2):6467.

GELAN, A. 2003. Local economic impacts: the British Open. Annals of tourism research, 30(2):406-425.

GETZ, D. 1993. Festivals and Special Events. (In Khan, M,A., Olsen, M.D., \& Var, T. eds. Encyclopaedia of Hospitality and Tourism. New York: Van Nostrand Reinhold. p.789-810.)

GETZNER, M. SPASH, C.L. \& STAGL, S. 2005. Alternative for environmental valuation. New York: Routledge.

HIGGINBOTTOM, K. 2004. Wildlife tourism: an introduction. (In Higginbottom, K. ed. Wildlife tourism: impacts and planning. Altona Vic: Common Ground Publishing.p. 2-11.),.

HORRIDGE, M. 2000. ORANI-G: A generic single-country computable general equilibrium model. CoPS Working Paper OP-93, Centre of Policy Studies, Monash University.

KANG, Y. \& PERDUE, R. 1994. Long term impact of a mega-event on international tourism to the host country: a conceptual model and the case of the 1988 Seoul Olympics (In Uysal, M. ed. Global tourist behaviour. International Business Press.)

$\mathrm{KOCH}$, M.H. 2005. Economic impact of biltong hunting in South Africa. Potchefstroom: Northwest University. (Hon. Tourism Management).

KOTTKE, M. 1988. Estimating economic impacts of tourism. Annals of tourism research, 15(1):122-33.

NIJKAMP, P. 2004. Environmental economics and evaluation. Northhampton: Edward Elgar Publishing Limited. 
PHASA. 2006. Statistics for the period November 2004 to September 2005. http://www.professionalhunters.co.za/htm. Date of access: 13 Nov. 2006.

PHILLIPS, G. 2005. Ecotourism: a SANParks perspective. (Paper delivered at the Ecotourism South Africa Confex at the Indaba Hotel Johannesburg South Africa on the 9-11 November 2005) Johannesburg (Unpublished).

PROFFESSIONAL HUNTERS ASSOCIATIONS OF SOUTH AFRICA SEe PHASA

RANDALL, J.E. \& WARF, B. 1996. Economic impacts of AAG conferences. Professional geographer, 48(3):272-84.

RITCHIE, J.R. \& GOELDNER, C. 1994. Travel, tourism, and hospitality research. $2^{\text {nd }}$ ed. London: Wiley \& Sons.

RESOSUDARMO, B.P. 2008. The Economy-wide Impact of Integrated Pest Management in Indonesia. ASEAN economic bulletin, 25(3):316-333.

SAAYMAN, M. 2000. En route with tourism. $2^{\text {nd }}$ ed. Potchefstroom: Leisure Consultants and Publications.

SAAYMAN, M. 2001. A marketing analysis of tourists visiting selected national parks in South Africa. Potchefstroom: Institute for Tourism Management and Leisure Studies.

SAAYMAN, A. \& SAAYMAN, M. 1997. Die ekonomiese impak van toerisme op Suid-Afrikaanse ekonomie. South African journal of economic and management sciences 21, Autumn.

SAAYMAN, A., SAAYMAN, M. \& NAUDE, W. 2000. The impact of tourist spending in South Africa: spatial implications. (Paper prepared for the Regional Science Association International (RSAI) International Symposium on Regional Development in South Africa, Port Elizabeth Technikon on 25 January 2000. Port Elizabeth. p. 1-18.

SAAYMAN, M. \& SAAYMAN, A. 2004. The economic impact of cultural events. South African journal of economic and management sciences, 7(4):629-642, Dec.

SAAYMAN, M. \& SAAYMAN, A. 2006. Creating a framework to determine the socio-economic impact of National Parks in South Africa: A case study of the Addo Elephant National Park. Tourism Economics. 12(4):619-633.

SOUTH AFRICAN TOURISM REPORT. 2004. South African Annual Tourism Report (provincial distribution). South African Tourism, Johannesburg, South Africa.

THORNTON, G. \& FEINSTEIN, K. 1999. South African tourism trends - an interim update of tourism talk. $5^{\text {th }}$ ed. Fishwicks: The Printers.

TYLER, G.J. 2008. Export Demand and Botswana's Beef Industry: A Computable General Equilibrium Approach. African development review, 8(2):59-67. 
TISDELL, C. \& WILSON, C. 2004. Economics of wildlife tourism. (In Higginbottom, K., ed. Wildlife tourism: impacts and planning. Altona Vic: Common Ground Publishing. p. 145-161.)

VAN DER MERWE, P. \& SAAYMAN, M. 2004. Managing game farms from an ecotourism perspective. Vanderbijpark: Ons Drukkers.

VAN DER MERWE, P., SAAYMAN, M. \& KRUGELL, W. 2004. Factors that determine the price of game. Koedoe, 47(2):105:13.

VAN DER MERWE, P. \& SAAYMAN, M. 2005(a). Game farms as sustainable ecotourism attractions. Koedoe, 48(2):1-11.

VAN DER MERWE, P. \& SAAYMAN, M. 2005(b). National profile and economic impact of biltong hunters in South Africa. Potchefstroom, Institute for Tourism and Leisure Studies.

VAN DER MERWE, P. \& SAAYMAN, M. 2005(c). Profile of biltong hunters in the North West Province: part 2. SA hunter, 20:50-51, May.

VAN HEERDEN, A. 2003. Economic impact of Aardklop National Arts Festival. Potchefstroom: PU for CHE. (Dissertation - MA.)

VAN HOVEN, W. 2005. Ecotourism and game ranching: why it works. (Paper delivered at the Ecotourism South Africa Confex at the Indaba Hotel Johannesburg South Africa on the 9-11 November 2005) Johannesburg (Unpublished)

VELLAS, F. \& BECHEREL, L. 1995. International tourism. London: MacMillan.

VENTER, J.P. 2006. Analysis of the hunting cluster: Limpopo Province. Paper presented at provincial workshop. Bela-Bela. 6-7 March 2006.

WALPOLE, M.J. \& GOODWIN, H.J. 2000. Local economic impacts of Dragon tourism in Indonesia. Annals of tourism research, 27(3):559-76.

WORLD TRAVEL AND TOURISM COUNCIL see WTTC

WTTC. 2005. Tourism Satellite Account. http://www.wttc.org/2004tsa/frameset2a.htm. Date of access: 12 Jan. 2006.

ZHANG, J. \& LEE, DJ. 2007. The effect of wildlife recreational activity on Florida's economy. Tourism economics, 13(1):87-110.

ZAMAGNI, S. 1987. Microeconomic Theory. An introduction. Padstow: TJ Press.

ZHOU, D., YANAGIDA, J.F., CHAKRAVORTY, U. \& LEUNG, P. 1997. Estimating economic impacts from tourism, Annals of tourism research, 42:76-89. 